\title{
НЕОСЯЖНІСТЬ БОГА ТА ЙОГО ІМАНЕНТНІСТЬ У БОГОМИСЛЕННІ МАКАРІЯ ЄГИПЕТСЬКОГО
}

Проблема інтерпретації взаємовідношення між Богом-Творцем і сотвореним Ним світом - характерна риса богословської думки Отців Церкви. Головний наголос святоотцівське богослов'я ставить на діаметральній протилежності між божественною трансцендентністю й іманентністю ${ }^{1}$, де абсолютна віддаленість Бога від світу, недоступність та непізнаваність, 3 одного боку, збалансовується Його всюдисущністю, всепроникністю і всеосяжністю - $з$ іншого. Богословський синтез цих двох підходів, цілісна інтерпретація онтологічної проблеми взаємозв'язку між потойбічним і поцейбічним Богом та пошук її поняттєво-концептуального вираження, без перебільшення, має першорядне тріадологічне значення як 3 огляду на адекватне розуміння Об'явлення Триєдиного Бога у світі, так і з потреби антропологічно-сотеріологічного обгрунтування можливості богопізнання, участі людини в Божій природі та іiі Обоження. Центральний пункт цієї проблеми - напруга між абсолютною “іншістю” внутрітроїчного буття (Богом in Se, ad intra, Божа theologia) й одночасною онтологічною “близькістю” Бога в Його об'явленні у світі (Бог pro nobis, ad extra, Божа oikonomia) через божественну благодать, силу, енергію. Саме з наголосу на винятковій вагомості та значущості цієї проблеми для богослов'я розпочинають книгу про богослов'я в XX ст. С. Гренц та Р. Ослон: “У своїх найкращих виявах християнське богослов'я завжди намагалося знайти рівновагу між двома спорідненими біблійними істинами - божественною трансцендентністю та божественною іманентністю. 3 одного боку, Бог трансцендентний щодо світу. Він самодостатній та існує незалежно від світу. Бог панує над всесвітом і приходить у наш світ ззовні. [...] 3 іншого боку, Бог іманентний світу. Це означає, що Він завжди присутній у своєму творінні. Господь приймає найдієвішу участь у всьому, що відбувається у всесвіті та історії людства [...] богослови у всі часи стикались

${ }^{*}$ Viktor Zhukovskyy, PhD - Chair of Theological Department, Ukrainian Catholic University (Lviv) [Віктор Жуковський, доктор філософії - Завідувач кафедри богослов'я, Український Католицький Університет (Львів)]; e-mail: viktor@ucu.edu.ua.

1 Така концептуальна полярність в онтології Бога перегукується 3 платонівським контрастом між сферою наявного буття і сферою приходу всього, що існує, до буття. Див. K. Anatolios, Athanasius. The Coherence of His Thought, London - New York 1998, 17. 
із необхідністю знайти таке формулювання християнського уявлення про природу Бога, яке би врівноважувало, стверджувало та стримувало у творчій напрузі божественну трансцендентність та іманентність”.

Чіткий наголос на трансцендентно-іманентній двовимірності Божої природи притаманний богословській думці Псевдо-Макарія Єгипетського. Дуже бракує цілісних і систематичних наукових досліджень, де б комплексно було розглянуто як питання апофатичного та катафатичного підходів цього аскетичного письменника до інтерпретації трансцендентності й іманентності Божої природи, так і збалансованого синтезу цих двох методів богословлення. Предметом нашого короткого дослідження є апофатичне й катафатичне богослов'я Псевдо-Макарія Єгипетського. Головною метою - представлення проблеми онтологічного розрізнення та єдності між Богом ad intra і Богом ad extra та їі концептуально-поняттєвого вираження в богословській думці Псевдо-Макарія.

\section{1. Апофатично-катафатична полярність та термінологічна про-} блематика. Богомисленню Макарія ${ }^{3}$ властива напруга подвійності між “внутрішнім” і “зовнішнім” як у сфері духовності й антропології, так і в питанні інтерпретації абсолютної іншості Божого Буття щодо світобудови та, водночас, Його надзвичайно близької присутності в усій сотвореній реальності світу й людини. Головним таким поділом в Макарієвому світобаченні, його космології й антропології є чітке розрізнення між Творцем і творінням, невидимим і видимим, духовним і чутливим ${ }^{4}$. Ця подвійність у його творах виявляється як концептуально, так і поняттєво ${ }^{5}$. Макарій не систематичний у представленні свого бачення проблеми розрізнення між недоступною і недосяжною природою Бога та божественними виявами “назовні”. Тексти Макарія насичені поетичними образами, властивими семітській літературі, що, з одного боку, ускладнює

\footnotetext{
${ }^{2}$ С. Гренц - Р. Ослон, Богословие и богословы ХХ века, Черкассы 2011, 9.

${ }^{3}$ Ми не заторкуватимемо проблеми авторства текстів Псевдо-Макарія і надалі вживатимемо ім'я Макарій. Про наукові дослідження корпусу творів, духовно-аскетичної спадщини і богословської думки Макарія див. К. Ware, Preface, в: Pseudo-Macarius, The Fifty Spiritual Homilies and the Great Letter, ed. and transl. G.A. Maloney, New Jersey 1992, c. XI-XVIII; M. Plested, A Survey of Recent Research on Macarius-Symeon (Pseudo-Macarius), VTQ 47 (2003) 431-440. Огляд та аналіз його богословської думки див. G.A. Maloney, Introduction, в: Pseudo-Macarius, The Fifty Spiritual Homilies and the Great Letter, c. 1-33; Г.В. Флоровский, Восточные Отцы V-VIII веков, Москва 1992, 146-161; H. Dörries, Die Theologie des Makarios/Symeon, Göttingen 1978; E.A. Davids, Das Bild vom Neuen Menschen. Ein Beitrag zum Verständnis des Corpus Macarianum, Salzburger Patristische Studien 2, Salzburg - München 1968; P. Hanstein, Die mystische Theologie Makarius des Aegypteps und die ältesten Ansätze christlicher Mystik, Bonn 1908.

${ }^{4}$ Пор. M. Plested, The Macarian Legacy. The Place of Macarius-Symeon in the Eastern Christian Tradition, Oxford 2004, 32-35.

${ }^{5}$ Пop. A. Golitzin, A Testimony to Christianity as Transfiguration: The Macarian Homilies and Orthodox Spirituality, в: Orthodox and Wesleyan Spirituality, ed. S.T. Kimbrough, Crestwood 2002, 129.
} 
систематизацію його підходів, з іншого - допомагає увійти в атмосферу богомислення, характерна риса якого - духоцентричний іманентизм ${ }^{6}$. В текстах Макарія простежуємо неясність і плутанину у використанні

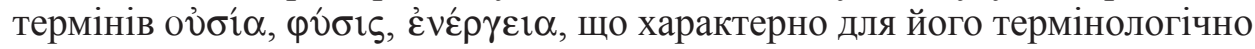
нечіткої богословської доби. Він недвозначно зазначає, що Бог - це схована божественна реальність ${ }^{7}$, недоступна для творінь, хоч люди й покликані до участі в Ньому 8 У Бесідi 16 Макарій чітко наголошує на тому, що Божа природа нескінченна і неосяжна 9 :

“Як Божу велич і неосяжність не вміщає у собі ні вишнє, ні нижнє, так само й Боже умалення, те, як Він применшує себе до таких, якими є малі й принижені, не можуть осягнути ні вишні світи, ні земні. Бо як велич, так і Боже умалення - неосяжні" 10 .

М. Плестед зазначає, що апофатизм Макарія подібний до апофатизму Кападокійських отців, які, полемізуючи з аріянцями і Євномієм, наголошували на незбагненності Бога. Вони проводили аналогію між незбагенністю Бога і людини, яка є Божим образом. Подібно і Макарій, в своєму апофатичному підході, використовує таку ж аналогію ${ }^{11}$.

Бог є одночасно схований і об'явлений. Апофатизм Макарія балансує між Божою недоступністю і гострим відчуттям Його проявів ad extra ${ }^{12}$. Хоч наголос Макарія на неможливості людини взяти участь у недоступній Божій сутності чіткий, використання ж терміна оひ่бí $\alpha$ доволі

${ }^{6}$ Пop. N. Russell, The Doctrine of Deification in the Greek Patristic Tradition, Oxford 2004, 241.

${ }^{7}$ Пop. Macarius Aegyptius (Magnus), Homiliae spiritualis II 1, 1.

${ }^{8}$ Пop. A. Hatzopoulos, Two Outstanding Cases in Byzantine Spirituality: The Macarian Homilies and Symeon The New Theologian, Analecta Vlatadon 54, Thessaloniki 1991, 265-266.

${ }^{9}$ Макарій в цій гомілії розгортає очевидний антиномічний підхід до розуміння природи Бога, наголошуючи на Його неописанності й неохопності, з одного боку, і всеохопності та всюдиприсутності, з іншого: "Бог неописанний і неохопний, являє Себе скрізь: і на горах, i в морі, і на дні безодні, не переходячи з одного місця на інше. [...] Він і на небі, Він і тут. $[\ldots]$ Бог безпристрасний, і все обіймає, тому що неописанний. [...] А якщо не стверджуєш, що Бог охоплює все - і геєну, і сатану, то цим дозволяєш зробити висновок, що Його можна описати тим місцем, в якому перебуває лукавий, і цим змушуєш шукати іншого бога, який вищий від Нього. Тому що Богові необхідно бути скрізь, вище всього. Проте, з огляду на таїнственність і витонченість Божества, темрява, яку Він обіймає, Його не охоплює" (Маcarius Aegyptius (Magnus), Homiliae spiritualis II 16, 5, ed. G.A. Maloney: Pseudo-Macarius, The fifty spiritual homilies and The great letter, c. 131); Тексти Макарія подаю у власному перекладі. "Небо, сонце і гори перебувають у самому Бозі й Ним звершуються" (ibidem II 7, 2, ed. Maloney, c. 132).

${ }^{10}$ Ibidem II 32, 7, ed. Maloney, c. 199.

${ }^{11}$ Пор. Plested, The Macarian Legacy, c. 55. Макарій наприклад зазначає, що так як Бог незбагненний, так само і душа людини та ії ум непізнавані. Див. Macarius Aegyptius (Magnus), Homiliae spiritualis I 18, 7, 1; II 49, 4. Людина не може порахувати думки, які в ній протягом дня, то як вона може претендувати на пізнання Божих думок. Пор. ibidem II 12, 2.

${ }^{12}$ Пop. Plested, The Macarian Legacy, c. 57. 
проблематичне. Автор Духовних гомілій декілька разів використовує цей термін у загальному сенсі Божої природи (фv́бıৎ), коли говорить про участь у ній людини ${ }^{13}$. Цікавий його коментар на Свангеліє від Луки, де він говорить про дари, якими Господь обдарував Марію (Лк. 10, 40-42). Макарій зазначає:

"Марії, яка полюбила Його і сиділа біля Його ніг, було дано не просто

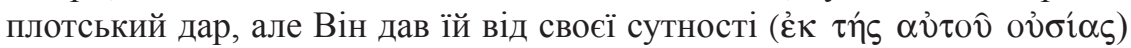
певну сокровенну силу. Слова, якими Бог із миром промовив до Марії, були духом і певною силою. Ці слова ввійшли в серце, стали душею в душі, духом у дусі, й божественна сила наповнила їі серце, тому що там, де витає ця сила, вона перебуває як невід'ємне осягнення. [...] Але згодом і $[\ldots]$ Марта [...] прийняла божественну силу у свою душу”"14.

Як бачимо, з одного боку, вжито термін ойбí $\alpha$, 3 іншого - автор декілька раз наголошує на таїнственній божественній силі, яку приймають у своє серце, душу і дух Марія та Марта. У цьому випадку сутність (о৩ْ $\left.\sigma^{\prime} \alpha\right)$ означає радше природу ( як про це сказано в Посланні апостола Петра (Пт. 1, 4).

В іншому уривку Макарій подібно говорить про святих, які своїми умами беруть участь у Божій “сутності і природі"” гального сенсу в розумінні сутності Бога, так і у вужчому значенні сутності Святого Духа й Ісуса Христа ${ }^{17}$.

“Тому і названий Він Христом, щоб і ми, будучи помазані тим самим єлеєм, яким Він був помазаний, могли стати Христами, у єдиній з Ним

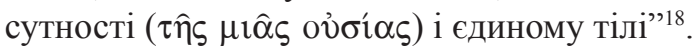

У першій колекції творів Макарія знаходимо подібні вислови, в яких, наприклад, автор зазначає, що:

${ }^{13}$ Пop. Hatzopoulos, Two Outstanding Cases in Byzantine Spirituality, c. 267-268.

${ }^{14}$ Macarius Aegyptius (Magnus), Homiliae spiritualis II 12, 16, ed. Maloney, c. 103-104.

${ }^{15}$ Пop. Hatzopoulos, Two Outstanding Cases in Byzantine Spirituality, c. 268.

${ }_{16}$ Пор. Macarius Aegyptius (Magnus), Homiliae spiritualis I 15, 38, 542. М. Горяча (Блаженства як основа духовного росту християнина. Духовна екзегеза Мт. 5, 3-8, “Наукові Записки Українського католицького університету” V, серія “Богослов'я” 2 (2015) 145-163), розглядаючи антропологічне вчення Макарія про об'явлення Божої благодаті в духовному житті подвижника, зазначає, що “душа може сутнісно (oÜsı̀̀dei) досвідчувати божественне світло". М. Horyacha, The Journey within the Heart. The Dynamic Anthropology of Pseudo-Macarius, Leuven 2012 (Dissertation, Katholieke Universiteit Leuven), 365. Як приклади, Макарій наводить видіння Павла на шляху до Дамаска, видіння первомученика диякона Стефана (Див. 2Кор. 3, 18; Дії. 9, 3; 26, 13; 7, 56; Йо. 14, 21). Благодать відкриває можливість пізнати

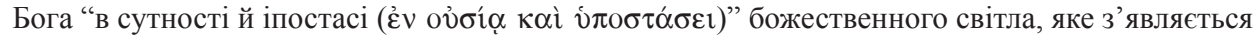
і світить у людській душі, пор. ibidem.

${ }^{17}$ Пop. Hatzopoulos, Two Outstanding Cases in Byzantine Spirituality, c. 267-268.

${ }^{18}$ Macarius Aegyptius (Magnus), Homiliae spiritualis II 43, 1, ed. Maloney, c. 219. 
“божественне світло сяє сутнісно й іпостасно в серцях ${ }^{19}$ вірних [...] божественне і сутнісне світло, яке з'являється і сяє у душах, є більшим, ніж сонячне світло"20.

Один із найцікавіших художніх засобів, які використовує Макарій на означення можливості людини перебувати в Бозі, - це образ “божественних крил” 21 , які одержує душа для того, щоб літати в “божественному повітрі", чи “повітрі Божества".

“Кров, принесеного в жертву Христа, окропила і зробила нас окриленими, давши крила Святого Духа, щоб ми могли вільно літати в повітрі

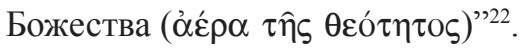

“[Людина] прагне злетіти в божественне повітря, у свободу Святого Духа, але не може, доки не одержить крил. Тому молімо Бога, щоб дав нам «крила, як у голубки» Святого Духа, щоб ми полетіли до Нього і відпочили (Пс. 54, 7)"23.

Цим поетичним образом “божественного повітря”, в якому повинна літати “окрилена" людська душа, Макарій ілюструє головну мету людини - єднання з Богом, де душа співдіє з благодаттю ${ }^{24}$ Духа Свято-

${ }^{19}$ Саме в серці відбувається, за Макарієм, боротьба між Божою силою і гріхом. Про місце серця та сердечну молитву у святоотцівському богослов'ї і духовності загалом та сирійській традиції зокрема пор. J.A. Mc Guckin. The Prayer of the Heart in Patristic and Early Byzantine Tradition, B: Prayer \& Spirituality in the Early Church, ed. P. Allen - W. Mayer - L. Cross, vol. 2, Queensland 1999, 69-108; S. Brock, The Prayer of the Heart in Syriac Tradition, "Sobornost" 4 (1982) fasc. 2, 131-142; K. Ware, Prayer in Evagrius of Pontus and the Macarian Homilies, B: An Introduction to Christian Spirituality, ed. R. Waller - B. Ward, London 1999, 20-26.

${ }^{20}$ Macarius Aegyptius (Magnus), Homiliae spiritualis II 17, 1-3, ed. Maloney, c. 135-136.

${ }^{21}$ Походження цього образу непевне. Це може бути неоплатоністичний образ польоту в Сдине, яке знаходимо у Плотіна (Enneades VI 9, 77 - 10, 28), як також поетичні образи орла і голуба в Юдействі. Пор. S. Burns, Divine Ecstasy in Gregory of Nyssa and Pseudo-Macarius: Flight and Intoxication, GOTR 44 (1999) 320.

${ }^{22}$ Macarius Aegyptius (Magnus), Homiliae spiritualis II 47, 2, ed. Maloney, c. 233.

${ }^{23}$ Ibidem II 2, 3, ed. Maloney, c. 45.

${ }^{24}$ Антропологічно-аскетичний вимір у розумінні природи і дії благодаті визначальний для Макарія. Він багато уваги приділяє характеристиці благодаті. Перш за все іiі дарує Бог не одноразово, а поетапно. Благодать діє поступово і різноманітно, очищає душу та ніколи не залишає людину. Дехто одержує їі швидко чи, навіть, раптово, а дехто повинен довго трудитись, щоби прийняти цей дар. Окрім того, для Макарія існують різні рівні сприйняття і дії благодаті: від короткого первинного досвіду до замешкання благодаті Духа в повноті відчуття і досвідчення. Благодать може зростати та зменшуватися, виявляти себе сильніше і слабше. Пор. Horyacha, The Journey within the Heart, с. 355-363. У Макарія можна виокремити чотири етапи у сприйнятті, пережитті та співдії благодаті, які, фактично, є етапами богопізнання й обоження. До них належать: сприйняття, видіння, просвітлення та об'явлення, див. ibidem, с. 363-366. Детальніше про вчення Макарія про благодать, пор. А. Катанский, Учение о благодати Божией в творениях древних св. отиев и учителей церкви до бл. Августина. Историко-догматическое исследование, "Христианское Чтение" 2 (1901) 
$г^{25}$. Ще одним цікавим і характерним образом, який використовує Макарій для того, щоб описати близькість та інтимність дії Святого Духа в людині є материнський характер цієї діяльності. Розуміння присутності і служіння Духа як "небесної матері" є наслідком сирійських християнський впливів на його богословсько-аскетичну думку ${ }^{26}$. Святий Дух “приходить у душі, яка Його шукає, і бере їх у свої руки життя, зігріває духовною, небесної їжею смачного, жаданого, святого, духовного і чистого молока" ${ }^{27}$.

2. Божественне світло, благодать, сила й енергія. Макарій належить до перших богословів, які, осмислюючи природу Божої діяльності у світі, наголошують на несотвореності Божої благодаті світла ${ }^{28}$. Для нього динамічна божественна присутність у світі загалом і в боголюдському спілкуванні зокрема - це просвітлювальна і переображувальна дія божественного світла. Це одна з центральних тем автора, і він багато про це роздумує в гоміліях, часто ставлячи знак рівності між поняттями благодать і світло Бога. Наприклад, у Гомілї 8 він, пояснюючи, що відбувається з подвижником у процесі молитовного сходження до досконалос$\mathrm{Ti}^{29}$, прирівнює природну, невіддільну, неперервну і вкорінену в людині дію благодаті $з$ постійною динамікою сяйва вогненного божественного полум'я в людському єстві. Інтенсивність цього божественного сяяння в людині залежить від іiі духовного стану, потреб і динаміки боголюдської синергії ${ }^{30}$. Марія Горяча в дослідженні антропології Макарія зазначає, що

137-171; И.В. Попов, Мистическое оправдание аскетизма в творениях преп. Макария Египетского, Свято-Троицкая Сергиева Лавра 1905, 101; П.С. Казанский, Учение о благодати nреп. Макария Египетского, “Прибавления к творениям святых отцов" 3 (1845) 125-146; J.S. Popovitch, Les voies de la connaissance de Dieu: Macaire d'Egypte, Isaac le Syrien, Symeon le Nouveau Theologien, Lausanne 1998, 74-89.

${ }^{25}$ Mop. Burns, Divine Ecstasy in Gregory of Nyssa and Pseudo-Macarius, c. 320.

${ }^{26}$ Mop. Plested, The Macarian Legacy, c. 43.

${ }^{27}$ Macarius Aegyptius (Magnus), Homiliae spiritualis II 47, 2, ed. V. Desprez, SCh 275, Paris 1980, 324. Іншим важливим уривком в якому Макарій описує буттєво близькі, інтимні взаємовідношення між благодаттю Духа і душею людини в якій поселяється Бог, є Macarius Aegyptius (Magnus), Homiliae spiritualis I 13, 2, 1-4.

${ }^{28}$ Пop. G. Mantzarides, Tradition and Renewal in the Theology of Saint Gregory Palamas, "Eastern Churches Review" 9 (1977) 15. A. Golitzin (A Testimony to Christianity as Transfiguration, с. 137-138) проводить паралель щодо значення поняття “несотворений”, яке використовується для того, щоб охарактеризувати природу Божої слави і Таворського світла, в текстах Макарія та Григорія Палами (1296-1359). Він називає низку місць, де Макарій наголошує на несотвореності божественних виявів "назовні" у вигляді “вічного світла", “несотворених вінців”, “божественної сили і вогню”, які “чужі нашій природі”. Діяльність “світла Святого Духа" також “надприродна”.

29 Детальніше про містичний досвід боголюдського спілкування в духовно-аскетичній думці Макарія див. Burns, Divine Ecstasy in Gregory of Nyssa and Pseudo-Macarius, c. 309-327.

${ }^{30}$ Про використання терміна “sunšrgeia” в текстах Отців Церкви див. Lampe, c. 1323-1324. 
порівняно з іншими Отцями Церкви він значно звужує поняття благодаті, розуміючи їі як божественну силу, яка, співпрацюючи з людською волею, допомагає подвижнику на духовному шляху до спасіння. Ця божественна сила, яка спасає, вже об'являлася у Старому Завіті як провідник пророків і праведних. Її Макарій називає також силою Духа, силою Христа чи силою Духа Христового, наголошуючи на єдності цієї сили, яка належить усім особам Трійці. Саме завдяки єдиній силі Христа і Святого Духа людина одержує дар богопізнання, спасіння і вічного життя ${ }^{31}$.

У богомисленні Макарія божественне світло - це світло Господнього Переображення, Його божественної слави ${ }^{32}$, в яке учасник Божого життя одягається і сяє, подібно як Христос засяяв на горі Тавор ${ }^{33}$.

“Це світло, являючись у серці, відкривало внутрішнє, глибинне і сокровенне світло. 3 цієї причини людина, цілковито поглинута цією солодкістю і спогляданням, не володіла вже собою"з4.

Для Макарія участь християн в “єдиній природі” Бога-це саме участь у божественному світлі:

“Як вогнем запалюють багато світильників і палаючих свічок, та всі свічки і світильники пломеніють й світять тим, що за природою єдине, так само й християни спалахують і сяють єдиним за природою божественним вогнем Сина Божого. I вони мають у своїх серцях палаючі свічки, i, перебуваючи ще на землі, світять перед Ним, подібно до Нього Самого"з3.

Нескінчений шлях прогресу в досконалості, яким таїнственно простує людина, полягає саме в постійному досвідному зростанні у сприйнятті та переживанні в собі дії божественного світла ${ }^{36}$. У Гоміліях він стверджує, що вінці, які одержують святі як нагороду за свої земні подвиги, - це

${ }^{31}$ Пop. Horyacha, The Journey within the Heart, c. 355.

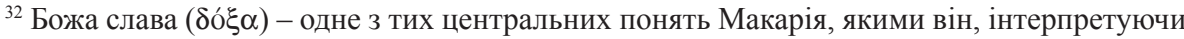
різні біблійні тексти, називає теофанію у світі. Для прикладу див. Macarius Aegyptius (Magnus), Homiliae spiritualis I 58, 1-2; I 17, 1; I 29, 2; I 2, 3; I 2, 14; II 12, 14; I 47, 1; I 29, 1; I 33, 2; I 4, 7; II 15, 38; III 16, 4; III 28, 2.

${ }^{33}$ Пор. Macarius Aegyptius (Magnus), Homiliae spiritualis 8, 2. Про Макарієве розуміння Божої слави й божественного світла через призму антропологічної та христологічної інтерпретації старозавітних образів слави, яку мав Адам перед гріхопадінням і сяяння лиця Мойсея, який зустрівся з Богом на горі Синай, а також світла божественної слави, якою засяяв Христос на горі Тавор під час Переображення, див. А.A. Orlov, Vested with Adam's Glory: Moses as the Luminous Counterpart of Adam in the Dead Sea Scrolls and in the Macarian Homilies, "Xristianskij Vostok" 10 (2002) fasc. 4, 740-755.

${ }^{34}$ Macarius Aegyptius (Magnus), Homiliae spiritualis II 8, 3, ed. Maloney, c. 82.

${ }^{35}$ Ibidem II 43, 1, ed. Maloney, c. 219.

${ }^{36}$ Пор. Russell, The Doctrine of Deification, c. 244. Для Макарія вчення про божественне світло займає особливе місце. Суттєвою особливістю його апофатичного богослов'я є те, що він не приділяє уваги розгляду питання божественної темряви у яку увійшов Мойсей, споглядаючи Бога на горі Синай. Для Макарія важливішим є світло божественної слави, яким 
“несотворені речі"37. Макарій часто наголошує на несотвореності різноманітних божественних виявів “назовні”. У його творах можна побачити, на перший погляд, суперечливі твердження щодо взаємовідношення між життям людини і Бога та ролі, яку в цьому відіграє Божа благодать ${ }^{38} .3$ одного боку, між людською душею та Богом існує абсолютна відмінність й безконечна онтологічна відстань. 3 іншого - Бог, замешкуючи у своїх творіннях, долає цю буттєву прірву між Ним і світом.

"Це - Бог, душа ж - не Бог. Це - Господь, а то - слуга. Це - Творець, а то - творіння. Це - майстер-виробник, а то - виготовлена річ. Немає нічого спільного між Божою природою і тією, що має душа. Але завдяки Його [...] любові і співчуттю, Йому приємно замешкувати в цих сотворених речах"з39.

Такий антиномізм віддаленості й доступності Божої предвічної природи щодо сотворенного буття притаманний для богословської думки Макарія.

3. Досвід боголюдської синергії і шлях до досконалості. Автор Гомілій подає визначальну вимогу для такого божественного "замешкання" в сотворених речах. Нею є трансформація людської особи в абсолютно інший, божественний, статус. Макарій пише:

"Наша душа повинна змінитись, трансформувавшись із теперішнього стану до нового - божественної природи"

Два протилежні твердження, які виражають одночасну недоступність і доступність природи Божого Буття, можливі. Це пояснюється тим, що Бог цілком інший від усього сотвореного i, водночас, у Ньому можна брати участь через енергії, які переображують людську душу ${ }^{41}$. Пізнання Бога через Його енергії має у богослов’ї Макарія конкретне духовнопрактичне значення і стосується синергійного процесу боголюдського

сяяло обличчя Мойсея після розмови з Богом. Див. Macarius Aegyptius (Magnus), Homiliae spiritualis II 5, 10. Детальніше про це див. Plested, The Macarian Legacy, с. 56.

${ }^{37}$ Macarius Aegyptius (Magnus), Homiliae spiritualis II 6, 7, ed. Maloney, c. 78.

38 Детальніше про богословську думку Псевдо-Макарія див. Davids, Das Bild vom Neuen Menschen, passim.

${ }^{39}$ Macarius Aegyptius (Magnus), Homiliae spiritualis II 49, ed. Maloney, c. 243: “ $\alpha \dot{\alpha} \lambda \lambda^{\prime}$ ' $v \tau \alpha \hat{v} \theta \alpha$

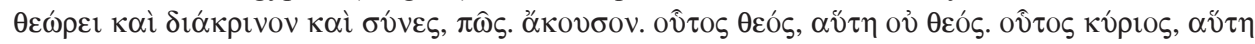

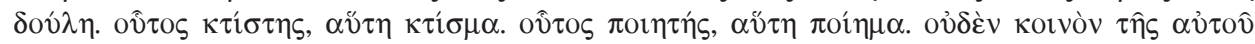

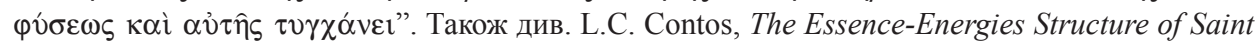
Gregory Palamas with a Brief Examination of its Patristic Foundation, GOTR 12 (1967) 283.

${ }^{40}$ Macarius Aegyptius (Magnus), Homiliae spiritualis II 44, 8, ed. Maloney, c. 225: " $\Delta \varepsilon \hat{\imath}$

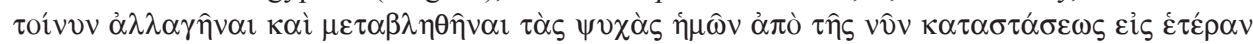

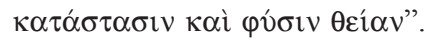

${ }^{41}$ Пор. M. Aghiorgoussis, Christian Existentialism of the Greek Fathers: Persons, Essence, and Energies in God, GOTR 23 (1978) 19-20. 
спілкування, в якому кардоцентричний вимір займає одне з визначальних місць у його аскетично-богословській думці. Саме

“серце того, хто схиляє коліна в молитві, наповнюється Божою енергією

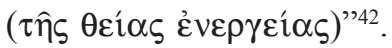

У цьому живому діалозі людини й Бога важливою є саме мудра дієва присутність Божої енергії в особі:

“Духовна енергія Божої благодаті (

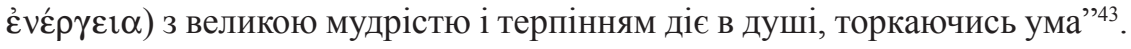

В іншому місці він зазначає, що “сила Божої благодаті перебуває в людині” 44 . Ця динаміка перебування не може бути односторонньою, без відповіді людини на дієву присутність енергії Божої в ній, а звершується лише в зустрічному синергійному процесі.

$\mathrm{B}$ особі Макарія бачимо перш за все аскетичного подвижника, богослова-практика, якого цікавить досвідний, духовно-практичний вимір особових боголюдських стосунків, у яких Бог об'являється ${ }^{45}$. Божа мета - цілісне переображення людської природи у сопричастя з енергією Святого Духа. Така участь у бутті Бога неможлива без очищення серця, знищення гріховних пристрастей, які $є$ головною перепоною на шляху до повноти цієї синергії ${ }^{46}$, і набуття чеснот:

"Він [Господь] хоче, щоб душа прийняла в себе Господа, причастилась його Духа й стала одним духом із Ним, щоб серце відновилось і преобразилось, пристрасті були погашені та знищені, і щоб у нас перебувала

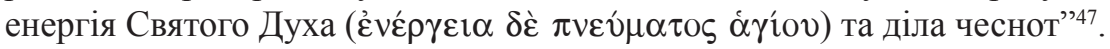

\section{Християнин-подвижник:}

“очікує Господнього приходу, щоб Той, з'явившись, очистив його від гріха, що перебуває в ньому. Насправді він не самотній у своїй праці, в тому

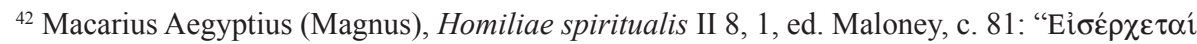

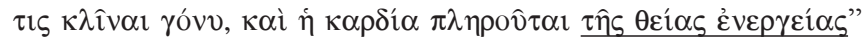

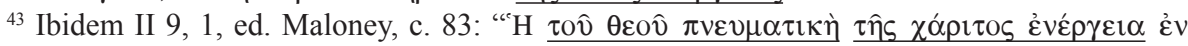

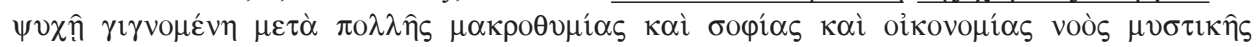
$\kappa \alpha \tau \varepsilon \rho \gamma \alpha \dot{\zeta} \varepsilon \tau \alpha \imath "$.

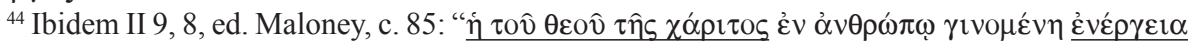

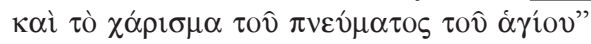

45 Детальніше про духовно-аскетичний вимір богослов'я Макарія пор. Golitzin, A Testimony to Christianity as Transfiguration, c. 129-156.

${ }^{46}$ Пop. J.C. English, The Path to Perfection in Pseudo-Macarius and John Wesley, "Pacifica" 11 (1998) 54-64.

${ }^{47}$ Macarius Aegyptius (Magnus), Homiliae spiritualis III 16, 53-57, SCh 275, 196: "iv $\alpha$

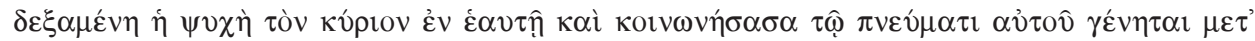

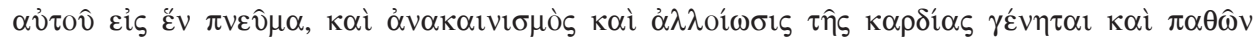

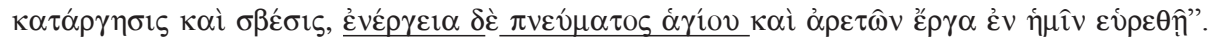


способі життя, який провадить, оскільки отримує те, на що надіється, адже Господь приходить і замешкує у ньому, в повноті досвіду й енергії

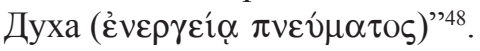

Наслідки ж такої боголюдської співпраці можуть виявлятися вже в земному житті. Боголюдська синергія веде до абсолютно нового типу існування людей, які причастилися Божої природи, в радості нового життя,“бо перебуваючи ще в тілі, вони насолоджуються приємним

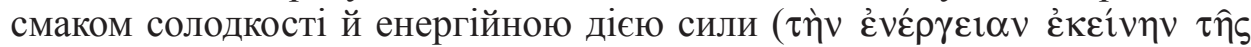
$\left.\delta v v_{\alpha} \mu \varepsilon \omega \varsigma\right)^{\prime 49}$. Енергія божественної сили - посередник, своєрідний Божий агент, в боголюдських взаємовідносинах.

4. Участь в божественній енергії й онтологія богопізнання. У богословській думці Макарія Ісус Христос й енергія Божої сили ( $\tau \hat{\eta} \varsigma$

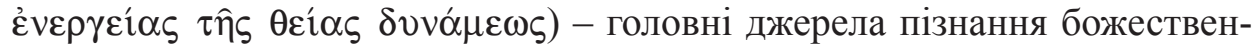
ної мудрості, християнської ідентичності та всієї повноти життя християнина. Гносеологічний вимір містичного входження в божественну реальність - це "правдивий шлях богопізнання через Божу силу й енергію

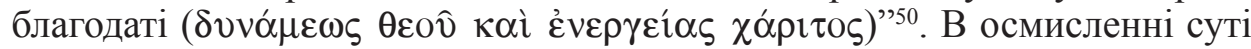
богопізнання Макарій проводить чітку межу між особою Ісуса Христа, Сина Божого, та енергією Божої сили:

“Як неможливо для риби жити поза водою, так для людини неможливо ходити без стіп чи бачити світло без очей, чи говорити без язика, чи чути

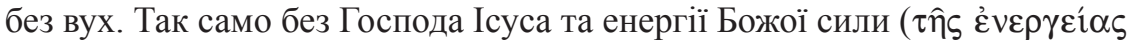

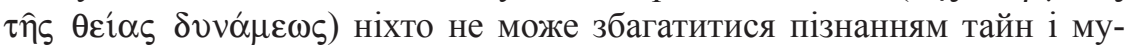
дрості Божої, не може бути християнином" ${ }^{\prime \prime}$.

Лише через внутрішню боротьбу, яка відбувається в серці людини, під

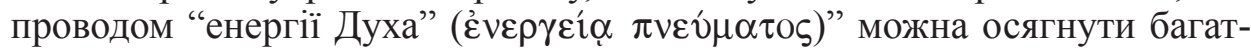
ство християнської віри:

"Ми повинні перш за все благати Бога, з боротьбою у серці й через віру, яку Він нам дарує, відкрити Його багатства, правдиві Христові скарби, в на-

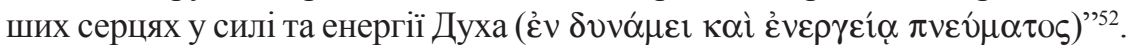

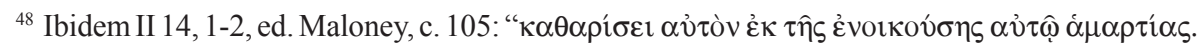

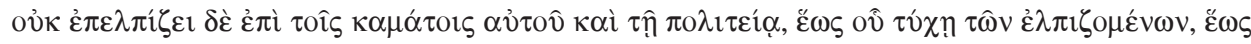

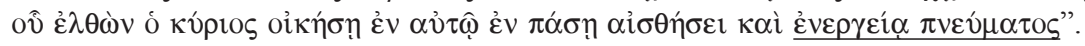

${ }^{49}$ Ibidem II 17, 2, ed. Maloney, c. 135-136

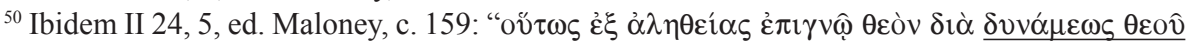

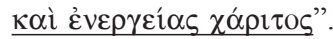

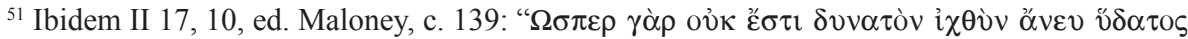

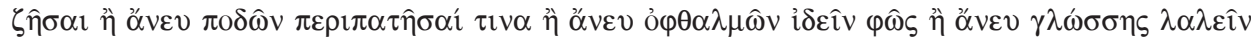

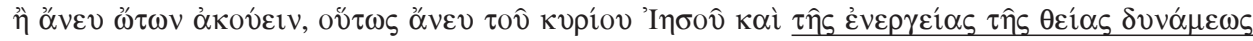

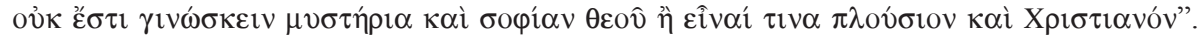

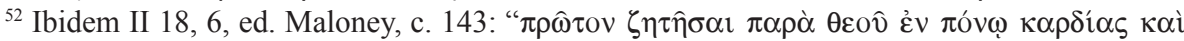


Християни, які живуть у співпраці з енергією Святого Духа, наближають-

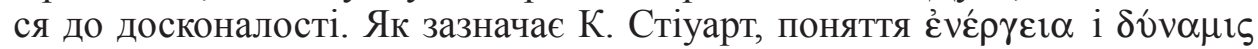
Макарій часто використовує коли говорить про певність відчуття, пережиття подвижником досвіду прийняття ним Святого Духа у єдності 3 Христом. Говорити про безпристрасність і досконалість можна, за Ма-

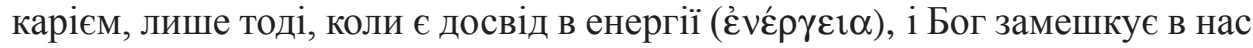

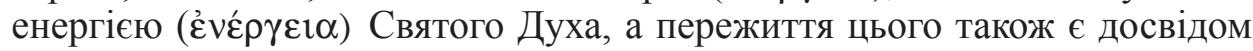

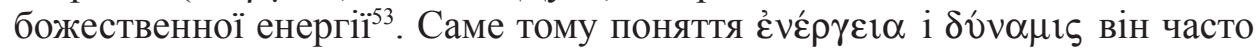
вживає поряд зі словами, які виражають впевненість у відчутті і досвіді

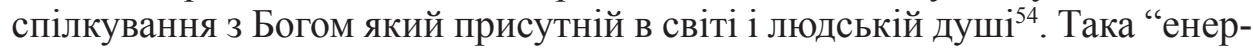
гійна” співпраця, дуже багата й різноманітна, поступово звершується на різних рівнях людського життя, в міру особисто-буттєвого просування людини назустріч об' явленням Божих енергій, які динамічно діють в людині, їі житті та діяльності. Макарій зазначає:

“Енергії Духа ( бувають недалеко від досконалості. Різноманітні вияви благодаті, про які ми говоримо, навіть якщо вони по-різному виражені, все одно діють на людей, що зростають. У цьому одна енергія слідує за іншою

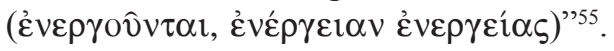

Божа сила й енергія відіграють роль своєрідної духовної, небесної, божественної одежі, в яку Господь зодягає душу людини:

“Якщо хтось нагий і йому бракує небесної та божественної одежі, якою

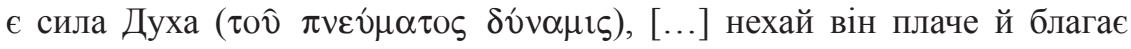
Господа, щоб одержати з Небес духовну одежу та одягнути в неї душу,

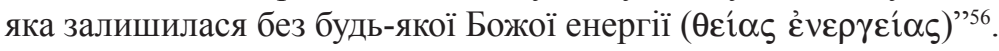

Богословське вчення Макарія про божественні сили й енергії має глибоко реалістичний і практично-досвідній вимір. У Гоміліях він постійно

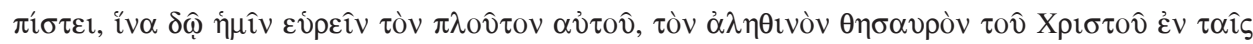

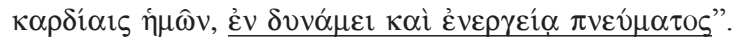

${ }^{53}$ Пор. C. Stewart, "Working the Earth of the Heart". The Messalian Controversy in History, Texts, and Language to AD 431, Oxford 1991, 96-97. Див. Macarius Aegyptius (Magnus), Homiliae spiritualis II 17, 12; II 14, 2; I 63, 2, 3.

${ }^{54}$ Пор. Stewart, "Working the Earth of the Heart”, с. 236-237. Окрім вказаних вже текстів також див. Macarius Aegyptius (Magnus), Homiliae spiritualis I 24, 13; I 30, 5; II 16, 1; III 25, 6, 1-2

${ }^{55}$ Macarius Aegyptius (Magnus), Homiliae spiritualis II 18, 10, ed. Maloney, c. 145. “T $\alpha \hat{v} \tau \alpha \delta \grave{\varepsilon}$

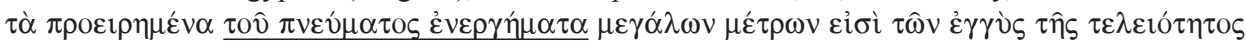

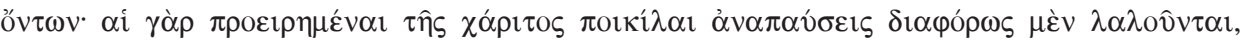

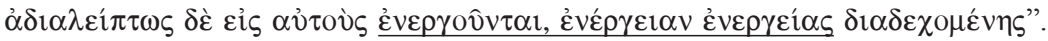

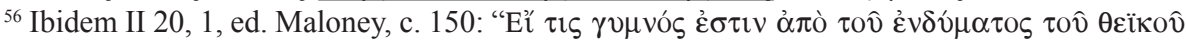

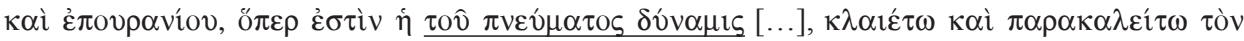

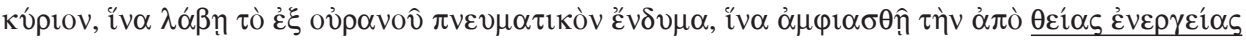

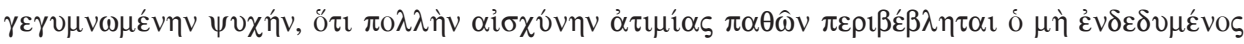

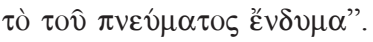


наголошує на вирішальній ролі живого досвіду в боголюдських стосунках, де людина повинна докладати зусиль, щоби брати участь у бо-

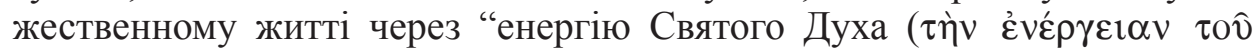

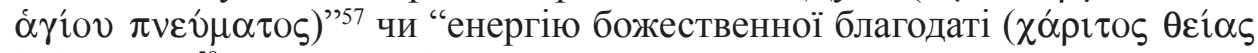

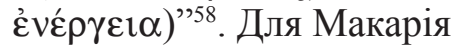

“християнство подібне до глибокого смакування, споживання і пиття іс-

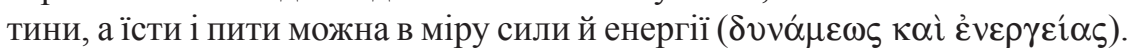
Це подібно до джерела, коли хтось дуже спраглий починає з нього пити. Потім, підчас пиття, його хтось відволікає і не дає досхочу напитися. Опісля ж, засмакувавши воду, спраглий ще більше запалюється бажанням втамувати спрагу і посилено шукає пиття. Так само й у духовному житті людина засмакувала та причастилася небесної поживи, але раптом під час їди ії забирають, і ніхто не дає їй насититися вповні”’59.

Макарій висловлює такий самий християнський реалізм живої участі в божественній силі й енергії ще чіткіше в Гомілії 7, де фактично дає визначення християнству, порівнюючи його з силою та енергією Святого Духа:

"Християнство - це не визнання словами простої віри, а сила й енергія

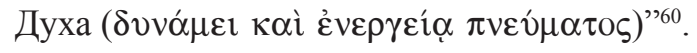

Він часто наголошує на прихованому вимірі божественної енергії, яка, неначе таїнственний божественний агент, діє на різних рівнях сотвореного світу. У людині божественні енергії об'являються в чеснотливому житті, для якого вони служать основою і натхненням. У людину “входить Божа сила й охоплює іiі члени і серце, полонить ум Божою любов”ю”б1. Відбувається взаємне замешкання Бога в людській душі і умі, а людини у Бозі. Таке взаємопроникнення не приводить до змішання природ ${ }^{62}$. I саме Божа любов вибудовує міст над “онтологічною прірвою між творінням і Творцем"63.

${ }^{57}$ Ibidem II 27, ed. Maloney, c. 179.

${ }^{58}$ Ibidem II 41, 2, ed. Maloney, c. 217.

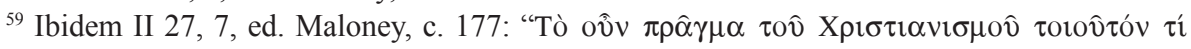

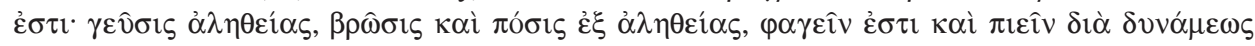

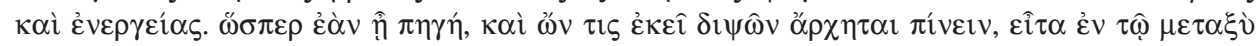

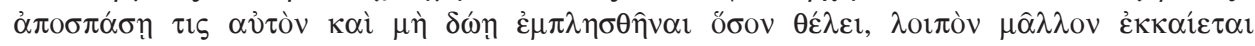

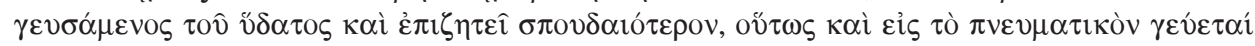

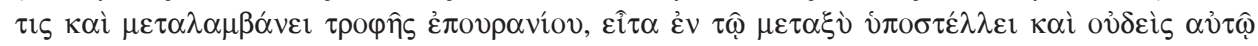
$\delta i \delta \omega \sigma \imath v \dot{\varepsilon} \mu \pi \lambda \eta \sigma \theta \hat{\eta} v \alpha \imath "$

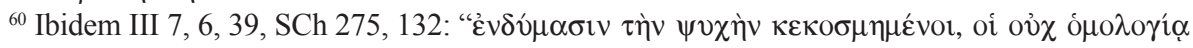

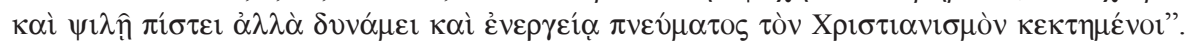

${ }^{61}$ Ibidem II 7, 3, ed. Maloney, c. 79.

${ }^{62}$ Пop. ibidem II 1, 2; II 6, 5; II 46, 4; II 49, 4.

${ }^{63}$ Plested, The Macarian Legacy, c. 31. 
Макарій зазначає, що між християнами є такі, які мають небесний скарб Духа з силою. Ці дари - невидимі і сховані для інших - благодатно виявляються в подвижниках, які живуть чеснотливо в пості, чуванні

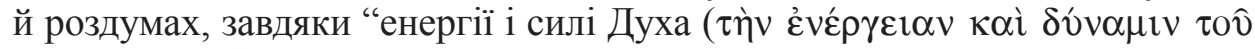
$\pi v \varepsilon v ́ \mu \alpha \tau o \varsigma)$ "“64. Така сама сила й енергія Духа - це джерело будь-якого дару та підтримки для людини. Царство Боже - це ніщо інше, як повнота божественної сили й енергії Духа: "Царство (Боже) приходить у силі

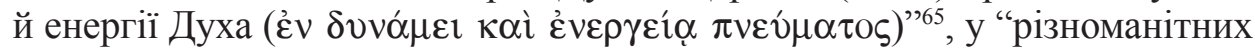

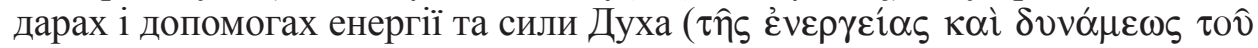
$\pi v \varepsilon v ́ \mu \alpha \tau \circ \varsigma)$ "“6 . Отож, “пневматологічний іманентизм” Макарія може бути лише завдяки його енергійній пневматології та христології, а відтак, енергійній тріадології, яка інтерпретує саму можливість будь-якої теофанії.

Сопричастя зі всією еклезіальною спільнотою теж залежить від сопричастя з Божою енергією. Якщо християнин не прийняв божественної енергії і не співдіяв із нею, то він опиняється поза Церквою, поза сопричастям зі Святим Духом і, як наслідок, позбавлений будь-якої можливості християнського почитання та правдивого пізнання Пресвятої Трійці. У цьому випадку досконалість недоступна і будь-які аскетичні зусилля задля участі в Божому житті безплідні, і саме причастя Бога стає ілюзорним. Макарій зазвичай чітко розрізняє між особою Святого Духа і Його особовою силою та енергією. Він тягло пише про силу й енергію Духа,

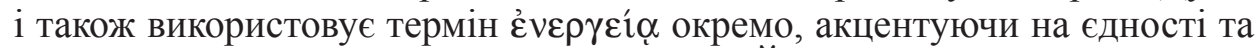
неподільності іпостасей Триєдиного Бога і Його енергій.

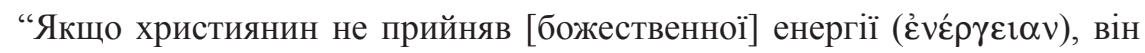
залишається іграшкою ілюзій, чужим для небесної Церкви первістків, немає сопричастя з духами праведних і досконалими людьми [...]. Ця людина не почала поклонятись Отцю в дусі й істині. Це той, хто не живе в Бозі й навіть не почав пізнавати Його"б7.

${ }^{64}$ Macarius Aegyptius (Magnus), Homiliae spiritualis III 7, 3, 11-19, SCh 275, 122: “oర̃

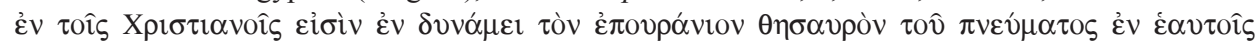

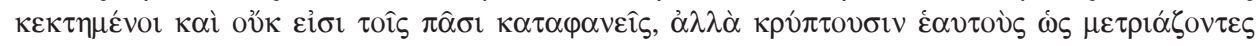

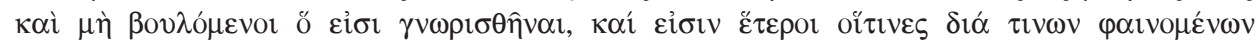

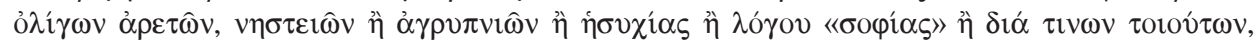

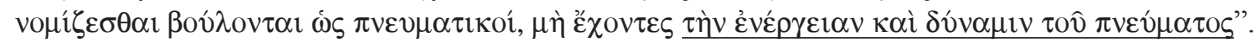

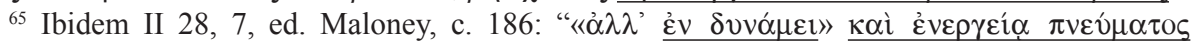

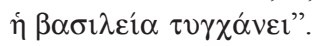

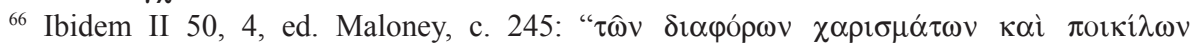

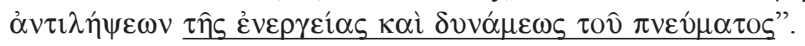

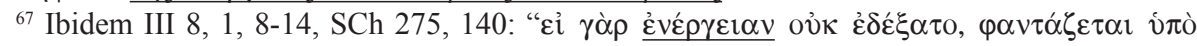

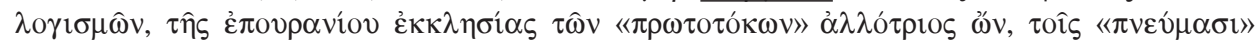

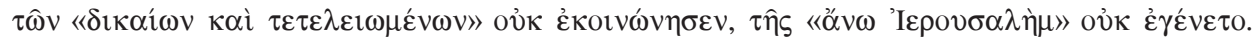

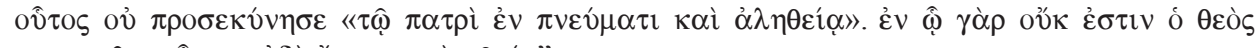

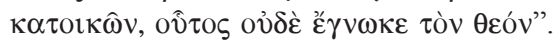


Отож, непізнавана божественна природа, залишаючись схованою та недоступною, виявляє себе в людському духовному досвіді як божественний енергійний дар іншого божественного світу.

“[А] духовні реалії невимовні, їх не можна висловити людським словом, якщо сам Дух не навчить відважну та вірну душу через досвід і за допо-

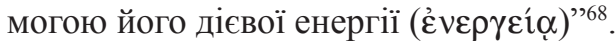

Божа енергія - це одночасно саме Божество і божественний інструмент. Усе походить від Бога, а це значить, що все звершується "через" і “в” божественній енергії. У Гомілії 18 Макарій, розглядаючи сотеріологічний аспект духовного подвижництва, зазначає, що гріх знищується

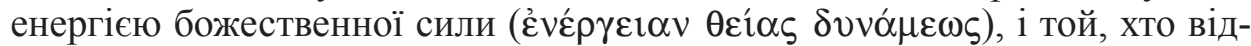

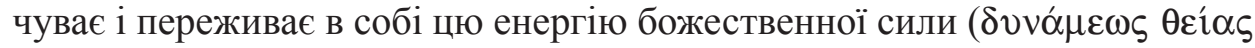

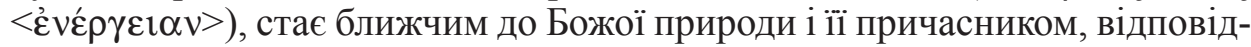

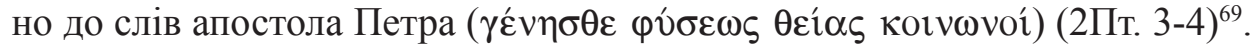
Причасник природи стає своєрідним грунтом для Божого насіння, яке в ньому засіюється, учасником Святого Духа, який і робить його сином правди ${ }^{70}$. Святий Дух проникає і наповнює цілу людину своєю енергією, яка замешкує та діє в людській природі, таїнственно вміщаючи та відкриваючи божественну істину й обдаровуючи великою радістю, щастям і потіхою. Головна мета цього процесу, щоб Господь перебував у людині

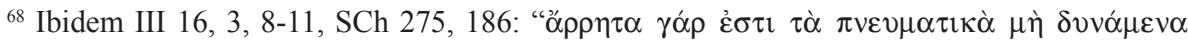

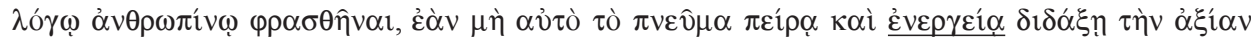

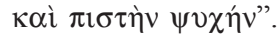

${ }^{69}$ Пор. 2 Пт. 3-4: “Бо його Божа сила дала нам усе до життя та побожності, завдяки спізнанню того, хто нас покликав своєю славою та силою! Завдяки їм нам були даровані цінні й превеликі обітниці, щоб ними ви стали учасниками Божої природи".

${ }^{70}$ Пop. Macarius Aegyptius (Magnus), Homiliae spiritualis III 18, 46-54, SCh 275, 222: “o” $\lambda \lambda$ o

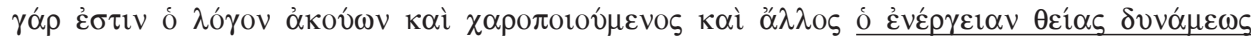

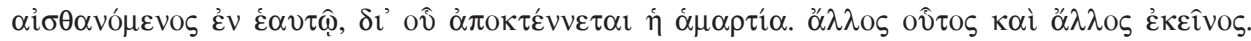

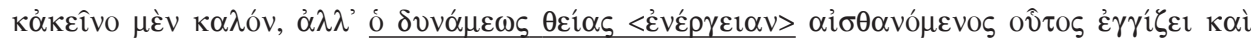

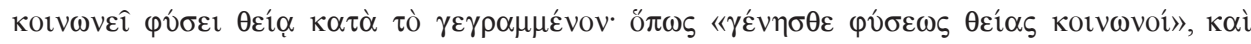

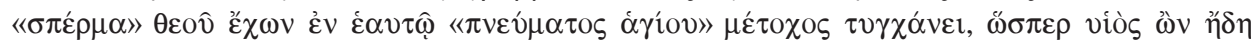

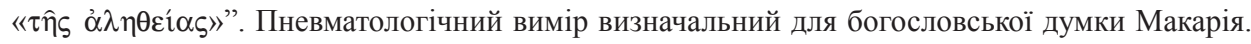
Християни, цілим своїм життям, залежать від сили Святого Духа, яка освячує. У діяльності вони покликані співдіяти своєю волею з Його силою. Віра відкриває кожному можливість пізнати дію Духа в душі, яка щодня здобуває досвід відчуття наближення до Христа. Див. ibidem III 10, 1. Живучи і наповнюючись Духом людина єднається 3 Богом та осягає Його Царство. Н. Рассел (Russell, The Doctrine of Deification, с. 241) називає це “духоцентричним іманентизмом” Макарія. Один із типових висловів Макарія, який він часто вживає, пояснюючи іманентну реальність перебування духа Божого в людині, - це фраза: “замешкання Духа в повній достовірності та відчутті”. Пор. Горяча, Блаженства як основа духовного росту

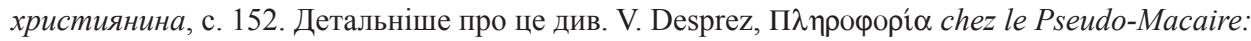
Plénitude et certitude... en pays grec, "Collectanea Cisterciensia" 46 (1984) 89-111. 


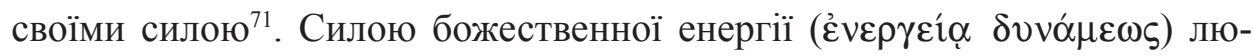
дина занурюється в Духа, переживає захоплення небесними таїнствами

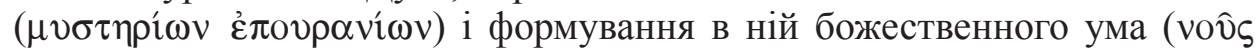
ع̌ $v \theta \varepsilon о \varsigma)^{72}$. Енергія Духа - це енергія, яка у правді, справедливості, красі та повному усвідомлені та відчутті творить добро в душі людини ${ }^{73}$.

“Тi, хто правдиво є дітьми Церкви Христової, виявляються через діла прав-

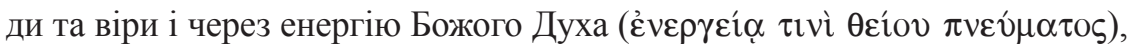
який приходить і замешкує в душі, покриваючи ії своїм покровом"”74.

Незважаючи на притаманну як для епохи Макарія, так і для нього самого термінологічну невизначеність, нечіткість та плутанину, в його богословленні простежуємо чіткий акцент на амбівалентності в інтерпретації природи Божого Буття. Макарій розрізняє між невимовним, неосяжним, недоступним і невмістимим для сотворінь величним Богом і тим Богом, який Себе дієво уприсутнює в духовному житті й подвигу християнина. У своєму аскетично-практичному підході духовного подвижника та отця Макарій використовує багату мову, щоб образно й термінологічно означити всеохопну і всенаповнювальну Божу дієву присутність у світі та людині. У його думці концептуально домінує “пневматологічний іманентизм”, який характеризує його богослов'я Божої присутності. Макарій виражає цю присутність через такі поняття, як: “дух”, сокровенна, “божественна сила”, “сила Божої благодаті”, “сила Духа”, яка єдина з “силою Христа”, “божественне повітря”, в якому може літати окрилена “божественними крилами" душа. Особливо важливі поняття, якими Макарій виражає теофанії у світі, - це несотворена "Божа благодать світла", Його "сяйво" та "божественна слава" й "Божа енергія", яку він також називає “духовна енергія Божої благодаті”, “енергія Божої сили”, “енергія благодаті”, “духовна енергія”, “енергія Божої сили”, “енергія Духа”, “енергія Святого Духа" й “енергія Божого Духа" тощо. Саме тому “пневматологічний іманентизм” Макарія головно визначається його енергійною пневматологією і христологією. Така енергійна тріадологія протилежна до апофатичних тверджень й антиномічно відображає концептуально єдину тріадологічну систему, глибоко пов’язану з духовно-аскетичною думкою Макарія.

${ }^{71}$ Пop. Macarius Aegyptius (Magnus), Homiliae spiritualis I 22, $2,9$.

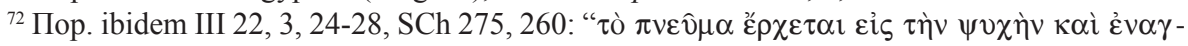

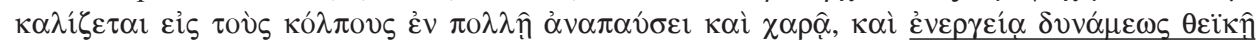

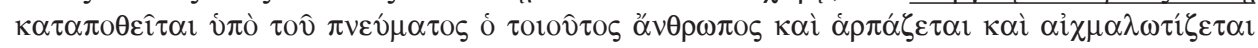

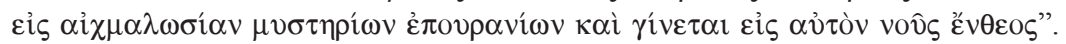

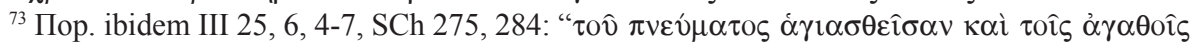

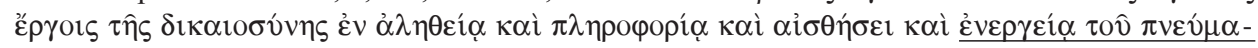

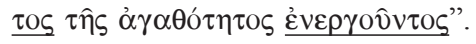

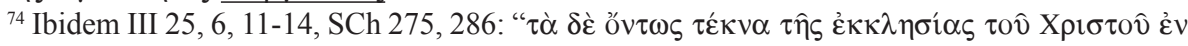

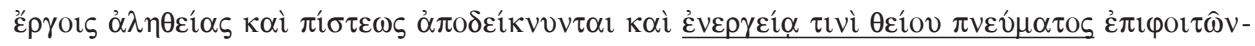

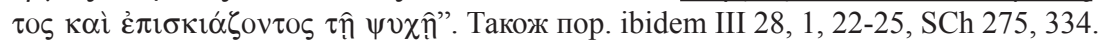




\title{
UNUTTERABLENESS OF GOD AND HIS IMMANENCY IN THE THEOLOGICAL THOUGHT OF MACARIUS OF EGYPT
}

\author{
(Summary)
}

In the article the author reflects on the problem of the ontological distinction between the transcendence and immanence of God in the theological thought of Macarius of Egypt. The focus of his analysis is on the apophatic approach to the interpretation of the unutterable, inaccessible and unknowable nature of God and the conceptual and terminological ways in which God's presence is expressed in created being. The main terms by which Macarius expresses God's absolute remoteness from the world, on one hand, and His presence in the world on the another, are analyzed. The researcher considers the spiritual and ascetic dimension of the anthropological and soteriological views of Macarius' theology through the prism of the pneumatology and christology.

\section{NIEWYRAŻALNOŚĆ BOGA I JEGO IMMANENCJA W TEOLOGICZNEJ MYŚLI MAKAREGO EGIPSKIEGO}

\section{(Streszczenie)}

Autor artykułu rozważa problem ontologicznego rozróżnienia między transcendencją i immanencją Boga w myśli teologicznej Makarego Egipskiego. W centrum jego analiz leży apofatyczny sposób interpretacji niewyrażalnej, niedostępnej i niepoznawalnej natury Boga, a także pojęciowe i terminologiczne sposoby wyrażania Bożej obecności w stworzonym bycie. Autor analizuje główne terminy stosowane przez Makarego, poprzez które wyraża on z jednej strony absolutne oddalenie Boga od świata, a z drugiej Jego obecność w świecie. Ponadto, poprzez pryzmat pneumatologii i chrystologii, rozpatruje duchowy i ascetyczny wymiar antropologicznych i soteriologicznych poglądów zawartych w teologii Makarego.

Key words: Macarius, apophatism, nature, essence, energy, power, light.

Słowa kluczowe: Makary, apofatyzm, natura, istota, energia, moc, światło.

\section{БІБЛІОГРАФІЯ}

\section{Джерела}

Pseudo-Macaire, Homiliae spiritualis, ed. V. Desprez: Oeuvres Spirituelles, Homélies propres à la Collection III, SCh 275, Paris 1980.

Pseudo-Macarius, Homiliae spiritualis, ed. G.A.Maloney: The Fifty Spiritual Homilies and the Great Letter, New York 1992.

\section{Література}

A Patristic Greek Lexicon, ed. G.W.H. Lampe, Oxford 1961.

Aghiorgoussis M., Christian Existentialism of the Greek Fathers: Persons, Essence, and Energies in God, GOTR 23 (1978) 15-41. 
Anatolios K., Athanasius. The Coherence of His Thought, London - New York 1998.

Brock S., The Prayer of the Heart in Syriac Tradition, "Sobornost" 4 (1982) fasc. 2, 131-142.

Burns S., Divine Ecstasy in Gregory of Nyssa and Pseudo-Macarius: Flight and Intoxication, GOTR 44 (1999) 309-327.

Contos L.C., The Essence-Energies Structure of Saint Gregory Palamas with a Brief Examination of its Patristic Foundation, GOTR 12 (1967) 283-294.

Davids E.A., Das Bild vom Neuen Menschen: Ein Beitrag zum Verstandnis des Corpus Macarianum, Salzburger Patristische Studien 2, Salzburg und München 1968.

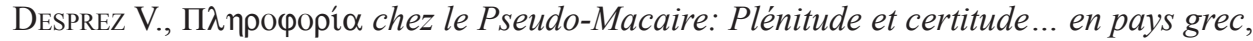
"Collectanea Cisterciensia" 46 (1984) 89-111.

Dörries H., Die Theologie des Makarios/Symeon, Göttingen 1978.

English J.C., The Path to Perfection in Pseudo-Macarius and John Wesley, "Pacifica" 11 (1998) 54-64.

Golitzin A., A Testimony to Christianity as Transfiguration: The Macarian Homilies and Orthodox Spirituality, B: Orthodox and Wesleyan Spirituality, ed. S.T. Kimbrough, Crestwood 2002, 129-156.

Hanstein P., Die mystische Theologie Makarius des Aegypteps und die ältesten Ansätze christlicher Mystik, Bonn 1908.

Hatzopoulos A., Two Outstanding Cases in Byzantine Spirituality: The Macarian Homilies and Symeon The New Theologian, Analecta Vlatadon 54, Thessaloniki 1991.

Horyacha M., The Journey within the Heart. The Dynamic Anthropology of Pseudo-Macarius, Leuven 2012 (Dissertation, Katholieke Universiteit Leuven).

Maloney G.A., Introduction, в: Pseudo-Macarius: The Fifty Spiritual Homilies and the Great Letter, ed. and transl. G.A. Maloney, New Jersey 1992, 1-33.

Mantzarides G., Tradition and Renewal in the Theology of Saint Gregory Palamas, "Eastern Church Review" 9 (1977) 1-18.

Mc Guckin J.A., The Prayer of the Heart in Patristic and Early Byzantine Tradition, B: Prayer and Spirituality in the Early Church, ed. P. Allen - W. Mayer - L. Cross, vol. 2, Queensland 1999, 69-108.

Orlov A.A., Vested with Adam's Glory: Moses as the Luminous Counterpart of Adam in the Dead Sea Scrolls and in the Macarian Homilies, "Xristianskij Vostok" 10 (2002) fasc. 4, 740-755.

Plested M., A Survey of Recent Research on Macarius-Symeon (Pseudo-Macarius), VTQ 47 (2003) 431-440.

Plested M., The Macarian Legacy. The Place of Macarius-Symeon in the Eastern Christian Tradition, Oxford 2004.

Popovitch J.S., Les voies de la connaissance de Dieu: Macaire d'Egypte, Isaac le Syrien, Symeon le Nouveau Theologien, Lausanne 1998.

Russell N., The Doctrine of Deification in the Greek Patristic Tradition, Oxford 2004.

Stewart C., "Working the Earth of the Heart". The Messalian Controversy in History, Texts, and Language to AD 431, Oxford 1991.

WARE K., Prayer in Evagrius of Pontus and the Macarian Homilies, B: An Introduction to Christian Spirituality, ed. R. Waller - B. Ward, London 1999, 14-30.

Ware K., Preface, в: Pseudo-Macarius: The Fifty Spiritual Homilies and the Great Letter, ed. and transl. G.A. Maloney, New Jersey 1992, xi-xviii.

*

ГорячА М., Блаженства як основа духовного росту християнина. Духовна екзегеза Mm.5, 3-8, “Наукові Записки Українського католицького університету” V, серія “Богослов” я" 2 (2015) 145-163. 
Гренц С. - Ослон Р., Богословие и богословы XX века, Черкассы 2011.

КАЗАнский П.С., Учение о благодати преп. Макария Египетского, “Прибавления к творениям святых отцов" 3 (1845) 125-146.

КАтАнский А., Учение о благодати Божией в творениях древних св. отиев и учителей церкви до бл. Августина. Историко-догматическое исследование, "Христианское Чтение" 2 (1901) 137-171.

Попов И.В., Мистическое оправдание аскетизма в творениях преп. Макария Египетского, Свято-Троицкая Сергиева Лавра 1905.

Флоровский Г.В., Восточные Отияь V-VIII веков, Москва 1992. 